IZA DP No. 5579

Informal Sector and Corruption:

An Empirical Investigation for India

Nabamita Dutta

Saibal Kar

Sanjukta Roy

March 2011 


\title{
Informal Sector and Corruption: An Empirical Investigation for India
}

\author{
Nabamita Dutta \\ University of Wisconsin-La Crosse \\ Saibal Kar \\ Center for Studies in Social Sciences, Calcutta \\ and IZA \\ Sanjukta Roy \\ World Bank and Internews Network
}

\author{
Discussion Paper No. 5579 \\ March 2011
}

IZA

P.O. Box 7240

53072 Bonn

Germany

Phone: +49-228-3894-0

Fax: +49-228-3894-180

E-mail: iza@iza.org

\begin{abstract}
Any opinions expressed here are those of the author(s) and not those of IZA. Research published in this series may include views on policy, but the institute itself takes no institutional policy positions.

The Institute for the Study of Labor (IZA) in Bonn is a local and virtual international research center and a place of communication between science, politics and business. IZA is an independent nonprofit organization supported by Deutsche Post Foundation. The center is associated with the University of Bonn and offers a stimulating research environment through its international network, workshops and conferences, data service, project support, research visits and doctoral program. IZA engages in (i) original and internationally competitive research in all fields of labor economics, (ii) development of policy concepts, and (iii) dissemination of research results and concepts to the interested public.
\end{abstract}

IZA Discussion Papers often represent preliminary work and are circulated to encourage discussion. Citation of such a paper should account for its provisional character. A revised version may be available directly from the author. 
IZA Discussion Paper No. 5579

March 2011

\section{ABSTRACT}

\section{Informal Sector and Corruption: An Empirical Investigation for India}

India is a country characterized by a huge informal sector. At the same time, it is a country where the extent of corruption in every sector is remarkably high. Stifling bureaucratic interference and corruption at every stage of economic activities is one of the main reasons behind high participation in informal and unregulated sectors. For economies characterized by high inequality and poverty, a useful tool for the government to pacify social unrest, is to choose a lower level of governance allowing substantial corruption in the system. Based on a study of 20 Indian states, we empirically show that higher corruption increases level of employment in the informal sector. Further, our analysis also shows that for higher levels of lagged state domestic product, the positive impact of corruption on the size of the informal sector is nullified.

JEL Classification: $\quad$ C12, C31, D23, J21

Keywords: $\quad$ informal sector, corruption, state domestic product, governance, India

Corresponding author:

Saibal Kar

Centre for Studies in Social Sciences, Calcutta

R-1, B. P. Township

Kolkata 700094

India

E-mail: saibal@cssscal.org 


\section{Introduction}

Informal sector plays a major role in employment generation, especially for the developing world (Agenor and Montiel, 1996; Harris-White and Sinha, 2007, Marjit and Kar, 2011, etc.). It is especially interesting and challenging to study the causes of growth in the informal sector and its impacts on the economy as a whole. The complexity of involving informal sector in such analyses arises typically because much of these activities are unrecorded and exists in the thin space between legality and illegality (De Soto, 2000; Dixit, 2004). Needless to say, any empirical investigation on informal sector is seriously constrained both by the availability of data and due to non-uniformity in the general description of what constitutes an informal sector. ${ }^{1}$

Among contested explanations behind growth of the informal sector in a country, a part of the literature finds that high level of corruption is an influential factor. Substantial corruption among law enforcement authorities, financial agencies, bureaucrats, politicians, and other regulators would essentially mean more bribery and greater rent seeking in the formal sector. ${ }^{2}$ Consequently, the cost of creating new businesses and staying in business in the formal sector may become quite costly. Thus, informal businesses may provide viable alternatives. Moreover, this is facilitated by passive compliance from governments incapable of creating jobs commensurate with growth in the labor force. Participation and existence in informal sector

\footnotetext{
${ }^{1}$ Recently, two studies by the ILO and Delhi Group (2007) and the NCEUS Report (2007) have gone a long way in identifying the range and depth of informal activities in the world. The NCEUS report in particular, defines zones within which informal activities may henceforth be categorized. In some other transition countries, such as Ukraine, a rich panel data set is available for measuring informal employment. Informal employment is largely a result of insufficient job opportunities in the formal sector, while informal self-employment is often voluntary (Lehmann and Pignatti, 2007).

${ }^{2}$ See Saha (2001) for the relationship between red tapes and bribery in the context of a developing country.
} 
replaces much of the formal transaction costs by bribes. This motivates us to explore the connections between corruption and the existence and persistence of informal sector in a developing country.

Marjit, Mukherjee and Kolmar (2006) provide a new perspective to this literature. They analyze causes behind emergence of an informal sector in a political economy framework. For economies characterized by high unemployment, high inequality and poverty, the government may choose a lower level of 'good' governance. This can be a conscious choice to maximize income for a large informal sector and avoid social conflicts and political disturbances. The extra legal occupations work as substitutes for social security and emerge as an innovative and effective re-distributive strategy. There should be little doubt that establishing this connection empirically can be a vexing exercise. However, the National Sample Survey Organization (NSSO) in India publishes a large data set over a substantially long period which we use for exploring the relationship.

We use data for 20 major states in India and combining it with data from the corruption database (Transparency International) find support for the hypothesis that a higher level of corruption leads to a larger informal sector. Further, our analysis shows that if the state had higher levels of income in the past, then the current impact of corruption on size of the informal sector is dampened.

Let us briefly elaborate on the connection between corruption and emergence of the informal sector. The informal sector often emerges as an alternative to costlier formal sector production, as a means to avoid taxes, environmental strictures and labor laws (de Paula and Scheinkman, 2010; De Soto, 2000; Dixit, 2004, etc.). Apparently, these are among the necessary conditions for existence. However, insufficient monitoring - due to both lack of resources and 
strategic choice by the state aided by corrupt practices, leads to stability. This may be a dominant factor why poorer countries encounter high incidence of informality vis-à-vis developed counterparts. With respect to developing countries, Dasgupta and Marjit (2006) shows that given both unionised labour and informal workers, the state will have reasons to undermine the strength of trade unions and stealthily promote the culture of informal sector to push forward liberal policies. However, Marjit, Ghosh and Biswas (2007) shows that tariff reduction and capital market reform in terms of lower interest rate may have conflicting effects on the size of the informal sector and hence, corruption in the economy. ${ }^{3}$

Finally, corruption is widely seen as an obstacle to the process of development. It distorts prices and raises transaction costs leading to inefficiency in the system. The persistence of petty and large-scale corruption are mostly reflections of robust (or, lack of) rule of law, transparency, accountability and regulations. Corruption, in economic literature, is interestingly looked at from two very different perspectives. It is either seen as a phenomenon that "greases the wheel" or "sands the wheel" of economic development, driven by varying cross-country cultural practices. Earlier, Leff (1964) argued that corruption could be a treated as a "second best" where bribes overcome indifference or hostility of a fickle government towards innovation (also see, Murphy et al. 1993). However, there is little evidence that even with cultural difference between notions of gifts versus bribes (Wei, 1999), corruption has less negative consequence for

\footnotetext{
${ }^{3}$ Regarding corruption and wage inequality in the presence of informal sector, see Mandal and Marjit (2010). Prevalence of large informal sector has previously been explained via non-adherence to labor laws. For example, Industrial Disputes Act (1947) in India defines activities in pro-worker states vis-à-vis pro-labor states (Besley and Burgess, 2004). The Act was designed to offer workers in the organized sector some protection against exploitation by employers. The Act comprising of seven chapters and forty sections, specifies powers of governments - state and central, labor being a 'concurrent' subject, courts and tribunals, unions and workers and the exact procedures that have to be followed in resolving industrial disputes. States independently amended the central law and made it look pro-worker, pro-labor or neutral. In the pro-labor states upholding greater rights of labor one expects less organized firms and hence emergence of larger informal sectors. For example, the total man days lost in West Bengal is more than $60 \%$ of what has been lost country-wise between 2000 and 2008; see Appendix 4.
} 
an economy. Kaufmann and Wei (1999) argue that "greasing the wheel" view is true only in a very narrow sense when the bad regulation and official harassment are taken as exogenous.

Recent papers document role of corruption as deterrent to formal activities. For example, Friedman et al. (2000) shows with cross-country evidence that entrepreneurs go underground not to avoid official taxes but to reduce the burden of bureaucracy and corruption. Similarly, Mauro (1995) finds significant negative impact of corruption on total investment to GDP ratio of a country. Wei (1997) finds clear evidence that corruption in host country is a significant deterrent of FDI inflow into the same. Tanzi and Davoodi (1997) finds that corruption increases the size of public investment at the expense of private investment, skews the composition of public expenditure away from development priorities towards expenditure on new equipments (also, Klitgaard, 1990). These imply diversion of expenditure away from infrastructure, health and education and encourage rent seeking behavior of public officials. Interestingly, Gupta, Davoodi, and Alonso-Terme (2002) show that high and rising corruption (ICRG index) increases income inequality and poverty. ${ }^{4}$

India continues to be one of the most corrupt nations in the world with a Corruption Perception score (compiled by Transparency International) of 3.3 (out of 10, with 10 meaning the least corrupt case) in 2010. India's nature of corruption, mostly seen as political, is a clear reflection of poor governance condition of the country. Correspondingly, it is also a country that has its majority of the workforce in the informal sector. According to the 2001 Census, $91 \%$ of the main workers in the total workforce are in the unorganized sector (Economic Survey, 2005-

\footnotetext{
${ }^{4}$ Also see, Johnson, Kauffman and Schleifer, 1997, for cross country evidence and Lavallée et al. (2008) for subSaharan Africa. Interestingly, Marjit, Rajeev and Mukherjee (2000) show that lack of complete information for the law-enforcing agent may help to partially prevent crime by making rewards and penalties more effective. In a similar framework involving tax-payers Marjit, Mukherjee and Mukherjee (2000) further shows that poorer sections lose more in corrupt systems than in honest systems.
} 
06). According to the National Sample Survey Organization (NSSO) estimates of 2004-05, only 7\% of the workforce in India belongs to the organized sector (Ratnam CSV: 2006, Economic Survey 2007- 2008). The diverse set of workers in the unorganized sector comprise of subsistence farmers, agricultural labor, daily wage earners, fishermen, servants/maids, dairy workers, artisans, vendors, retailers, weavers, traditional producers of handlooms, carpenters, garage mechanic, chauffeurs, producers using basic and primitive technologies, etc. and these individuals may either be entrepreneurs or workers in Directory and Non-Directory enterprises. Apart from these, a large number of contractual workers in private and semi-government formal sector units often do not receive compensations commensurate with labor laws in the country, including minimum wage. Thus, the term "unorganized labor" is defined in the Indian context as those workers who have not been able to organize themselves in pursuit of their common interests due to certain constraints like casual nature of employment, ignorance and illiteracy, small and scattered size of establishments, etc. ${ }^{5}$ The proportion of unorganized workers in India is much higher in the agrarian sector, building and construction industry and among home-based workers. However, despite overwhelming existence of the sector, statistical information on the intensity and accuracy of the same vary significantly.

Essentially therefore, we offer the missing disaggregated evidence on emergence of informal sector for a large country with wide regional variations. Rest of the paper is arranged as follows. Section 2 explains the data. Section 3 discusses the empirical methodology and benchmark results. Section 4 carries out some robustness analysis and Section 5 concludes.

\footnotetext{
${ }^{5}$ NCEUS (2007) provides more recent definition and classification of activities under the informal sector, which we follow closely.
} 


\section{Data}

The data has been considered from various sources. The dependent variable, level of employment in the informal sector, is taken from the Ministry of Statistics and Program Implementation (MOSPI)'s National Data Warehouse of Official Statistics. The reports and publication in this database are based on Annual Survey of Industries, NSS and Economic Census as also secondary data available in the Warehouse. The data is taken from the publication titled "Informal Sector and Conditions of Employment in India”, 2004-05. ${ }^{6}$ For our benchmark specifications, we consider proportion (per 1000) of informal sector (propriety and partnership) workers within each industry group across states. We consider total workers in both urban and rural sectors, workers only in the urban sector and workers only in the rural sector. We consider several industries ranging from Manufacturing, Construction, Real Estate, Education, etc.

The data for Corruption comes from Transparency International’s Corruption database. The data consists of corruption in the public sector. Eleven public sectors are considered that include Police (Crime/Traffic), Judiciary (Lower Courts), Land Administration, Municipal Services, Govt. Hospitals, Electricity (Consumers), PDS (Ration Card/ Supplies), Income Tax (individual assesses), Water Supply, Schools (up to 12th Std.) and Rural Financial Institutions (for farmers) ${ }^{7}$. We consider the composite score of corruption as well as individual scores in the respective sectors. Further, the TI Database on India is the most widely used state wise database on corruption and no other datasets encompass such an extensive sample as well as detailed

\footnotetext{
${ }^{6}$ It is obtained from the seventh quinquennial survey on employment and unemployment conducted in the 61st round of NSS during July, 2004 to June, 2005. The survey was spread over 7,999 villages and 4,602 urban blocks covering 1,24,680 households (79,306 in the rural areas and 45,374 in the urban) and enumerating 6,02,833 persons (3,98,025 in the rural areas and 2,04,808 in the urban).

${ }^{7}$ Note that, agriculture in India is almost entirely in the informal sector.
} 
sector wise corruption data.

The data on state domestic product (SDP) is taken from the Central Statistic Organization (CSO, GoI). SDP is considered at factor cost at constant prices of $1999-2000$. The other controls include population, literacy and Human Development Index (HDI). While Population and literacy are taken from Economic Survey 2008 - 2009, HDI data has been taken from National Human Development Report 2001.

Before testing the empirical associations, we offer some graphical representation of the raw data. To contextualize our hypothesis we look at growth rate of the unorganized manufacturing sector in different states in the past two decades. This exercise gives us a historical trend on the prevalence of unorganized sector across the country. ${ }^{8}$ Figure 1 (A and B) shows growth of unorganized manufacturing sector for different states for two different census periods - economic census of 1980 and 1990. We consider the share of unorganized manufacturing enterprises for each state to total unorganized manufacturing enterprises in India. For rural India, while most of the states considered in the sample show a decline in unorganized manufacturing, Orissa, West Bengal and Andhra Pradesh stand out as exceptions. Urban India, however, has more exceptions in this regard, namely Madhya Pradesh, Haryana, Delhi, West Bengal, Maharashtra, Andhra Pradesh, Gujarat and Kerala.

While Figure 1 describes share of unorganized manufacturing for 20 states under our consideration, Figure 2 focuses on four specific states - West Bengal, Maharashtra, Andhra Pradesh and Kerala. According to Besley and Burgess (2004), the first two are pro-worker and

\footnotetext{
${ }^{8}$ We could not provide the same graphs for the present decade because of absence of comparable data. This is also the reason we could not use past years in our empirical analysis and undertake a panel estimation. However, the data for 1980 and 1990 still adds to our analysis and understanding of the trend in unorganized sector across Indian states.
} 
the latter two, pro-employer states as derived from the classification of amendments of the Industrial Disputes Act (1947) in India. West Bengal passed largest number of pro-worker amendments since 1977 and has a declining formal manufacturing base. Maharshtra and Gujarat on the other hand showed tremendous growth in organized manufacturing during the same period. Thus, classification according to the Industrial Disputes Act does not explain high incidence of unorganized enterprises in Andhra Pradesh and Tamil Nadu (Figure 1) which are pro-employer and both of these have share of informal sector higher than West Bengal, which is infamous for extensive loss of man-days due to factory lock-outs and sustained labormanagement conflicts along with other political disturbances (see Appendix 4). In other words, while Industrial Disputes Act, 1947, may be an important explanatory factor, there is still a strong case for seeking other explanations, such as corruption-informality linkage as we establish shortly. Appendix 1 provides the list of states used in the paper and Appendix 2 provides the summary statistics.

We like to provide a brief interpretation of the corruption database. The Transparency International (TI) Database captures the extent of corruption of a state or a country from the perspective of citizens - how much corruption is experienced by the common man and what do they perceive about the future. Though the database does not capture the corruption existent among large businesses and small entrepreneurs, it is a representation of the corruption level of a state from the citizens’ point of view. So, despite reservations against perception based indicators, it captures responses by households directly and indirectly affected by various types of corruption in the state. 


\section{Empirical Methodology and Benchmark Results}

\section{A. Ordinary Least Square (OLS) Specifications}

We aim to investigate the impact of corruption on the size of the informal sector at the state level for a sample of 20 India states. For our benchmark specifications, we consider ordinary least squares (OLS) specifications. Further, due to data constraints we consider cross sectional specifications. Although data on informal activities over a span of about 25 years is available from the NSS at 5-year intervals, matching data on corruption is hard to come by. Therefore, we restrict this analysis to the cross-section of 2004-05 and intend to capture the long run implications once subsequent rounds of NSS are available in future.

Thus, our empirical specification is as follows

Informal $_{i}=\alpha_{1}+\alpha_{2}$ Corruption $_{i}+\alpha_{3} S_{S D P_{i}}+\alpha_{4} S D P_{i}^{2}+\alpha_{5}$ Inter $_{i}+\varepsilon_{i}$

where Informal ${ }_{i}$ is the level of informal employment per 1000 workers ( for both propriety and partnership) for state $i$ for the census period 2004-2005. Corruption ${ }_{i}$ is the composite score of corruption for state $i$ for the period $2004-2004 . S D P_{i}$ denotes state domestic product for state $i$ for the census year 2000-2001. $S D P_{i}^{2}$ aims to capture the non-linear impact of state domestic product on the level of employment in the informal sector. Along with Corruption and SDP, our variable of interest is Inter $r_{i}$ as well. Inter $r_{i}$ is the interactive impact of corruption and SDP on the level of employment in the informal sector. A positive coefficient of Inter will imply that for given levels of SDP, a unit rise in corruption will raise the level of employment in 
the informal sector. On the other hand, a negative coefficient of the same will suggest that given levels of SDP, a unit rise in corruption will lower the level of employment in the informal sector.

Figure 3 presents scatter plots for total (urban + rural) informal employment, urban informal sector employment and rural informal sector employment. As can be seen from the figures, the slope of Figure 1(c) is least positive. Yet, overall it suggests that a higher level of corruption leads to a larger informal sector.

Table 1 presents the benchmark results. Column (1) represents employment in the informal sector per 1000 individuals for both the rural and urban sector. While column (2) represents employment in the informal sector per 1000 individuals for only the urban sector, column (3) represents the same for the rural sector. As can be seen from Table (1), SDP and $S D P^{2}$ are significant for all three specifications. The sign of the coefficients of $S D P$ and $S D P^{2}$ implies that SDP has a concave relationship with the level of employment in the informal sector.

As SDP rises for a state, the level of informal employment goes up but the rate of increase occurs at a diminishing rate.

While the coefficient of corruption of corruption is positive for all three specifications, it is significant only for the first two specifications. Thus, it implies that as corruption rises, level of employment in the informal sector goes up. Inter is significant for the specification in Column (2) only but the coefficient is negative for all the specifications. As mentioned before, the negative coefficient suggests that for given levels of SDP, a unit rise in corruption, lowers the size of the informal sector. In order to fully understand the impact of corruption on the informal sector, we need to consider the following partial derivative 


$$
\frac{\text { SInformal }_{i}}{\text { SCorruption }}=\alpha_{2}+\alpha_{5} S D P_{i}
$$

Based on equation (2), it is possible to define a threshold level of SDP, SDP*, the level at which $\frac{\text { Informal }_{i}}{\delta \text { Corruption }_{i}}=0$ or a unit rise in corruption has no impact on the level of employment of the informal sector. Based on the figures of Column (2) specification in Table (1), $S D P^{*}=$ 65814. Thus, for all states whose $S D P \geq 65814$ in 2000-01, the impact of corruption on informal employment is zero. Further, though SDP has a concave relationship with size of the informal sector, the partial derivative of the dependent variable with respect to SDP will give us a clearer picture. The following partial derivative is considered

$$
\frac{\text { SInformal }_{i}}{\delta S D P_{i}}=\alpha_{3}+2 \alpha_{4} S D P_{i}+\alpha_{5} \text { Corruption }_{i}
$$

Based on our results, while $\alpha_{3}$ is positive, $\alpha_{4}$ and $\alpha_{5}$ are negative. Taking the average levels of SDP and corruption for our sample and considering the coefficients from Table 1, $\frac{\delta \text { Informal }_{i}}{\delta S D P_{i}} \approx 0.01$. This implies that an unit rise in SDP leads to an increase in the size of the informal sector by 0.01 unit. The higher the value of SDP, the lower will $\frac{\delta \operatorname{SIformal}_{i}}{\delta S D P_{i}}$ be. It should, however, be noted here that reduction in the size of the informal sector is not contingent on a zero level of corruption because that, in most cases, is unachievable. Novelty of the result lies in the fact that for a given level of corruption, a rising SDP holds the key to a shrinking 
informal sector in the economy. ${ }^{9}$

In Table (2), we include the Human Development index (HDI). HDI takes into account factors like life expectancy, educational attainment and income. The results in Table (2) are quite similar to that in Table (1).

\section{B. Addressing Endogeneity}

While our benchmark results offer interesting directions, the OLS estimates might be biased and inconsistent due to the presence of endogeneity issues. As our analysis shows, corruption is an important determinant of the size of the informal sector in each state. But, it is also plausible that the presence of informal sector generates corruption in a state. The very presence of large informal sector implies unregistered and unaccounted activities, which might be the progenitor of various forms of interlinked corruption - driving the dependent and independent variables into a loop of causality. To overcome this problem we run Two Stage Least Square (2SLS) specifications.

The obvious challenge we face here is the task of finding efficient instruments. With no state-level study on corruption in India to fall back on, we turn to cross country evidence on corruption. The extant literature on corruption has identified socio-demographic factors like schooling and population to be important determinants of corruption (see, Ali and Isse, 2003; Brunetti and Weder, 2003; Knack and Azfar, 2003; Tavares, 2003; Van Rijckeghem and Weder, 1997). So, we consider literacy levels and population data for the period 2000-01 across states as our instruments.

\footnotetext{
${ }^{9}$ This is reiterated when we check the association between SDP and incidences of poverty (data taken from Transparency International). A higher SDP, as expected, is associated with steeply declining incidences of poverty implying greater economic opportunities for the population.
} 
Appendix 3 provides the first stage results. The F statistic $(=6.95)$ is above conventional levels and it ensures that the used instruments are relevant. Table 3 provides the results from 2SLS specifications. The estimates obtained are IV estimates and are robust to heteroskedasticity. Our results remain robust. We again find that the results are most significant for the urban sector, though the coefficients for the total informal figures are weakly significant. Sargan's test for all the specifications shows that overidentifying restrictions cannot be rejected at levels well above the conventional level. In terms of defining the threshold level of SDP, at

which corruption has no impact on the size of the informal sector, $S P^{*}=56900$ for column (1) specification in Table (3). This threshold is approximately the same for the specifications in columns (2) and (3). IV estimators under heteroskedasticity may not be efficient. So we re-run the specifications with 2 step feasible efficient GMM estimator. The results are presented in columns (4) to (6) of Table 3 and are similar.

\section{Robustness}

We carry our analysis further by breaking down the composite corruption score for different sectors. Based on Transparency International (TI) ranking, these sectors can be needbased or basic. As mentioned in the data section, the need-based sectors considered are rural financial services (RFI), Income Tax, Municipal Services, Judiciary, Land Administration and police. The basic sectors consist of Schooling (up to $12^{\text {th }}$ grade), Water Supply, PDS (Ration Card/ Supplies), Electricity (Consumers) and Government Hospital. Tables (5), (6) and (7) present results with sector-wise corruption for employment in informal sector in both urban and rural sector, only urban sector, and only rural sector respectively. 
Table (4) shows that corruption in certain sectors is more sensitive to the size of the informal sector relative to others. Corruption in sectors like Municipal services, PDS/ Ration and Government Hospitals, lead to a larger informal sector. At the same time, higher SDP mitigates the adverse impact of corruption in the same sectors. The results in Table (6) are similar. We check the robustness of the findings in Table (4) by running IV and GMM specifications. For the IV specification, our results are similar, though statistical significance is not retained in certain cases. For the total sample, we get statistical significance for water supply, PDS/ration and municipal service. For the urban sub-sample, statistical significance is retained in case of Judiciary as well. The rural sub-sample retains statistical significance only in case of Water Supply. The retention of statistical significance for the above services is intuitive because municipal services, public distribution system and water supply are prone to corruption and can be traded in the illegal market. The relationship is unambiguously stronger in case of urban samples, where the alternatives to each of these facilities are many and that the respective departments are readily amenable to agent level corruption. Clearly, these are also the services that demand maximum government resources particularly in the rural areas where operations by private firms are at extremely low. Hence, a state with bad governance would have a greater tendency of such services being affected by corruption and by virtue of their importance market imperfections yield large informal arrangements.

The results in the previous section consider overall employment in the informal sector. We, further check our results by breaking down total employment in the informal sector by industry classifications for urban and rural areas together as well as urban and rural sectors separately. The results are presented in Table 4. The industries considered are Manufacturing, 
Construction and Education. As can be seen from the table, the results are strongly significant for Manufacturing Industry, except for rural sector.

\section{Conclusion}

Our study offers an interesting empirical analysis to the growing literature on informal sector by adopting a political economy framework. The analysis is novel because to our knowledge, this is the first empirical investigation on the corruption-informality linkage on India. More importantly, the results show that a higher level of corruption leads to a larger informal sector and account for a high level of employment. Interestingly, as state-level productivity rises the positive impact of corruption on the size of the informal sector reverses itself. In fact, for higher levels of state domestic product prevalence of high corruption shrinks the informal sector under all specifications considered. The study is also an attempt at generalizing isolated cases on such linkages. It also verifies and turns around previously unaccounted for explanations on state characteristics (such as implementation of labor laws and industrial laws) and the existence of informal sector in India. Here, rise in corruption unambiguously raises the size of the informal sector when we identify states with SDP lower than a critical level. Determination of the critical SDP below which corruption and level of informal activity reinforce each other is an important step towards policy targeting. To the extent that high SDP shrinks informal activities the message is clear. However, in recent times, states such as West Bengal reported that $42 \%$ of its SDP is generated in the unorganized sector (Human Development Report, 2004). Thus, unless the formal sector's share in SDP is sufficiently high, the relationship between corruption and informal sector at a critical SDP may suffer from circularity of arguments. In future attempts we intend to disentangle the sources of income, investigate relations between corruption and per 
capita income, poverty and inequality, ease of doing business (India ranks $132^{\text {nd }}$ globally, and major cities where large informal sector spawns include poor ranks for Mumbai at 10, Kolkata at 17, World Bank-IFC, 2009) etc. with consequent implications for growing informality at the state level. Finally, the empirical results from India motivates us to construct appropriate theory in near future where one could generate combinations of tax and bribe to observe emergence and sustenance of informal activity vis-à-vis formal business. 


\section{References}

Ali, M. A and Isse, H. S (2003), Determinants of Economic Corruption: A Cross- Country Comparison, Cato Journal, 22, 3, 449-466.

Agenor, P. R. and Montiel, P (1996), Development Macroeconomics. New Jersey: Princeton University Press.

Besley, Tomothy and Burgess, R (2004), "Can Labor Regulation Hinder Economic Performance? Evidence from India," The Quarterly Journal of Economics, MIT Press, vol. 119(1), 91-134

Brunetti, A and Weder, B (2003), A Free Press is Bad News for Corruption, Journal of Public Economics, 87, 1801-1824.

de Paula, A and Scheinkman, J (2009) The Informal Sector: An Equilibrium Model and Some Empirical Evidence from Brazil, Second Version, PIER Working Paper Archive 10-024, Penn Institute for Economic Research, Department of Economics, University of Pennsylvania, revised 26 Jul 2010.

Dasgupta, I. and Marjit, S (2006): Evasive reform: informalisation in a liberalised economy with wage-setting unions, in B. Guha-Khasnobis and R. Kanbur, (Eds.) Informal Labor Markets and Development, NY: Palgrave-MacMillan.

De Soto, Hernando (2000), The Mystery of Capital. USA: Basic Books.

Dixit, Avinash (2004), Lawlessness and Economics: Alternative Modes of Governance. New Jersey: Princeton University Press.

Friedman, E, Johnson, J, Kaufmann, D and Zoido-Lobaton, P (2000), Dodging the grabbing hand: the determinants of unofficial activity in 69 countries, Journal of Public Economics 76, 459-493.

Gupta, S, Davoodi, H and Alonso-Terme, R (2002), Does Corruption Affect Income Inequality and Poverty? Economics of Governance, 3, 1, 23-45.

Harris-White, B and Sinha, A (2007), Trade Liberalization and India's Informal Economy. Oxford: Oxford University Press.

ILO and Delhi Group (2007), Concepts, Definitions and Sub-classifications, (draft chapter 2). Manual on Surveys of Informal Employment and Informal Sector. Geneva: ILO.

Johnson, S, Kaufman, D and Shleifer, A (1997), The Unofficial Economy in Transition, Brookings Papers on Economic Activity, Economic Studies Program, The Brookings Institution, 28, 2, 159-240. 
Kaufmann, D. and Wei, S.-J (1999), Does 'Grease Money' Speed up the Wheels of Commerce? National Bureau of Economic Research Working Paper 7093, Cambridge MA.

Klitgaard, Robert (1989), Incentive Myopia, World Development, 17, 4, 447-59.

Knack, S and Azfar, O (2003), Trade Intensity, Country Size and Corruption, Economics of Governance, 4, 1-18.

Lavallee, E, Razafindrakoto, M and Rouband, F (2008), Corruption and trust in political institutions in sub-Saharan Africa, ELDIS: UNDP, Afrobarometer.

Leff, N.H. (1964), Economic Development through Bureaucratic Corruption, American Behavioral Scientist, 8, 3, 8-14.

Lehmann, H and Pignatti, N (2007), Informal employment relationships and labor market segmentation in transition economies: Evidence from Ukraine, IZA Discussion Paper \# 3269, Bonn.

Mandal, B and Marjit, S (2010), Corruption and wage inequality? International Review of Economics and Finance, 19, 166-172.

Marjit, S and Kar, S (2011), The Outsiders: Economic Reform and Informal Labour in a Developing Economy, New Delhi, London: Oxford University Press, 2011

Marjit, S, Ghosh, S and Biswas, A (2007), Informality, Corruption and Trade Reform, European Journal of Political Economy, 23 (3), 777-89.

Marjit, S, Rajeev, M and Mukherjee, D (2000), Incomplete Information as a Deterrent to Crime, European Journal of Political Economy, 16, 4, 763-73.

Marjit, S, Mukherjee, V and Mukherjee, A (2000), Harassment, Corruption and Tax Policy, European Journal of Political Economy, 16, 1, 75-94.

Mauro, Paolo (1995), Corruption and Growth, Quarterly Journal of Economics, 110, 681-712.

Murphy, Kevin, Schleiffer, A and Vishny, R (1993), Why is Rent-Seeking So Costly to Growth? American Economic Review, 83, 2, 409-414.

National Commission for Enterprises in the Unorganised Sector (NCEUS) 2007. Report on Conditions of Work and Promotion of Livelihoods in the Unorganised sector. New Delhi: Government of India.

National Sample Survey Organization (2004-05), Informal Sector and Conditions of Employment in India (Part-I and II), Ministry of Statistics and Programme Implementation, Government of India. 
Saha, Bibhas (2001), Red Tape, incentive bribe and provision of subsidy, Journal of Development Economics, 65, 113 - 133.

Tanzi, V and Davoodi, H (1997), Corruption, Public Investment, and Growth, International Monetary Fund Working Paper, 97/139.

Transparency International (2004), Global Corruption Report, UK.

Van Rijckeghem, C and Weder, B (1997), Corruption and the Rate of Temptation: Do Low Wages in the Civil Service Cause Corruption?. IMF Working Paper WP/97/73.

Wei, S.-J. (1999), How taxing is corruption on international investors? Review of Economics and Statistics, 81, 4, 1-12.

Wei, Shang-Jin (1997), Why is Corruption So Much More Taxing Than Tax? Arbitrariness Kills, NBER: Mass, The National Bureau of Economic Research Working Paper 6255, November.

World Bank and IFS (2009), http://www.doingbusiness.org/rankings 
Figure 1: Share of Unorganized Manufacturing Enterprises to Total Unorganized Manufacturing Enterprises for different states in India for 1980 and 1990 (Rural and Urban)

\section{A. Rural}

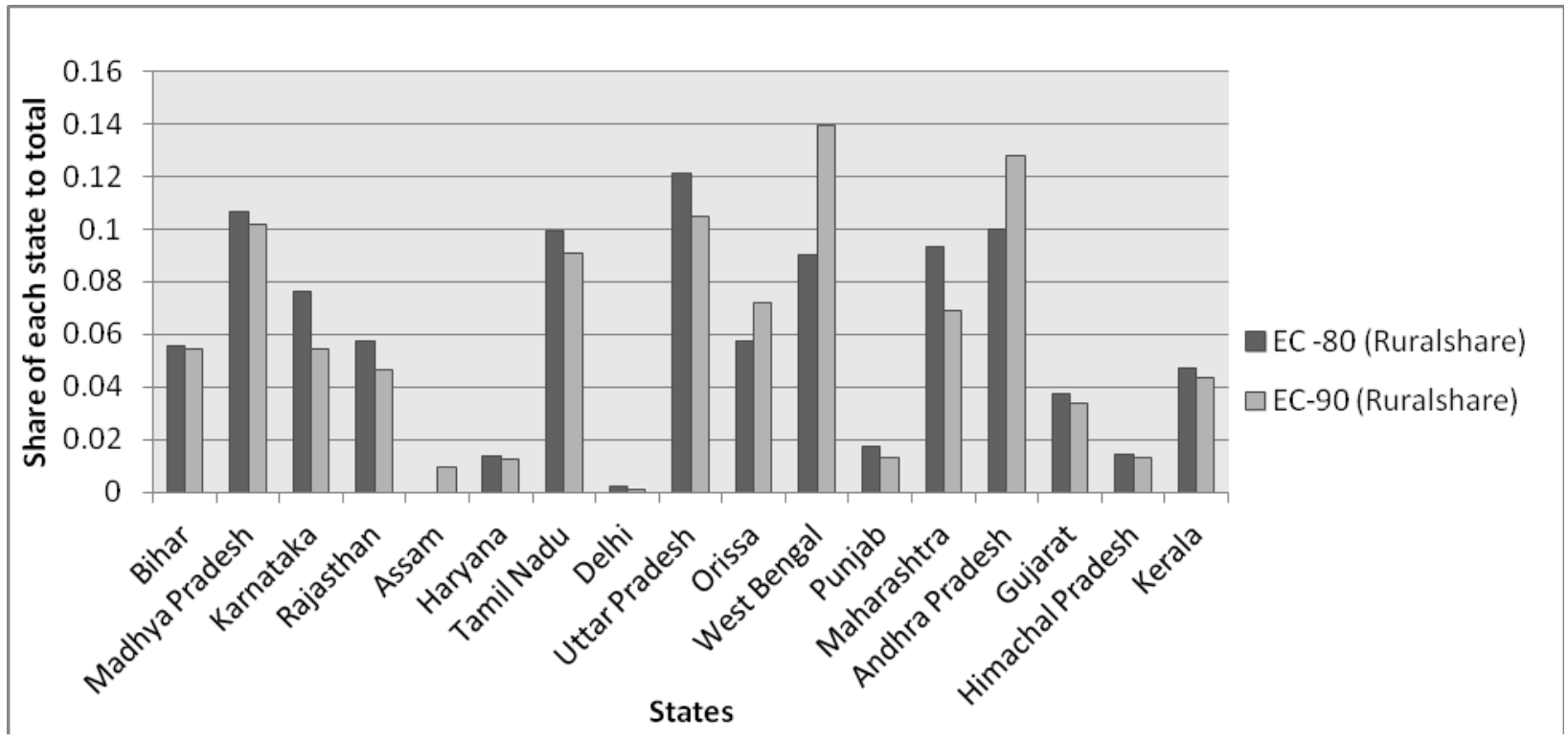

B. Urban

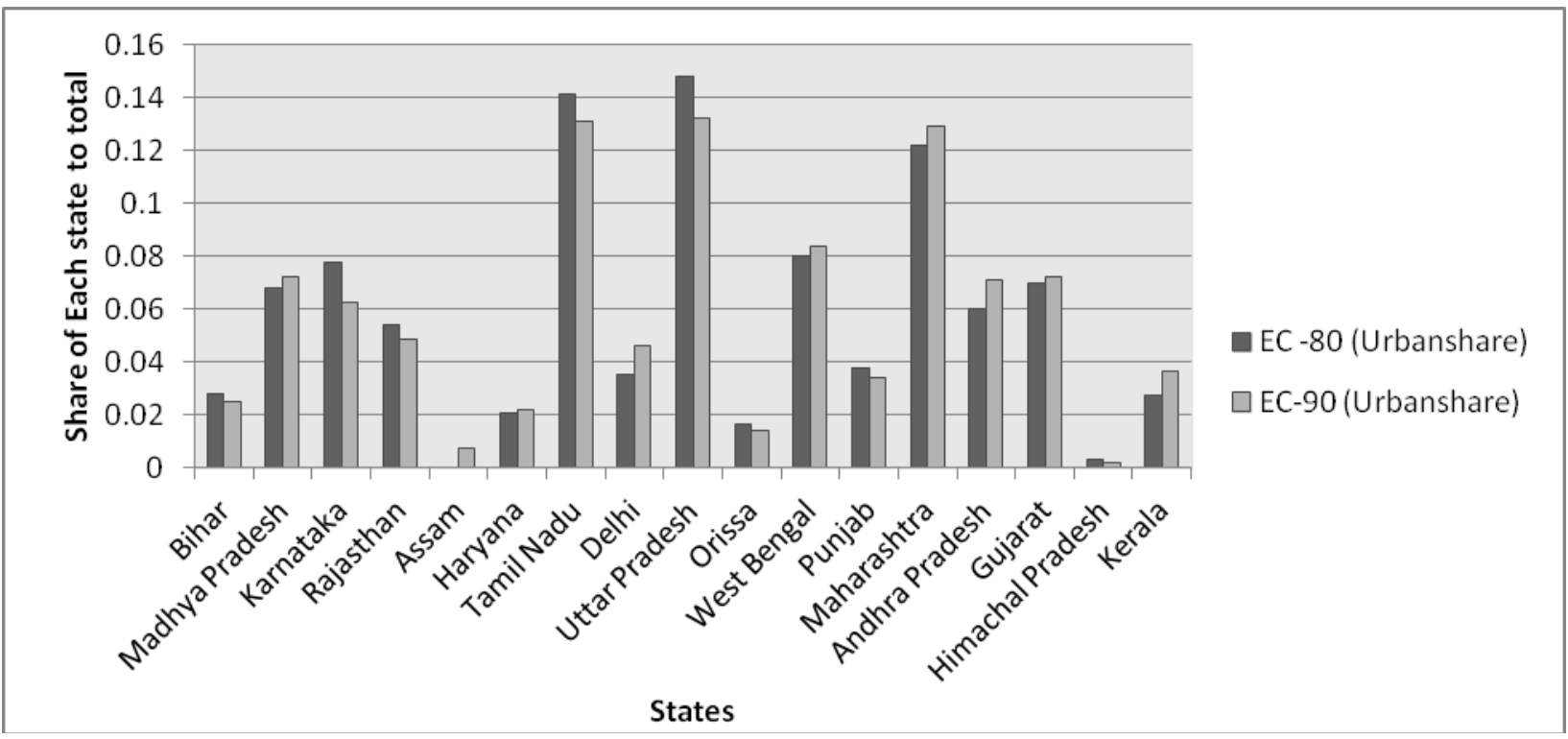


Figure 2: Share of Unorganized Manufacturing Enterprises to Total Unorganized Manufacturing Enterprises in four states of India in 1980 and 1990

A. West Bengal

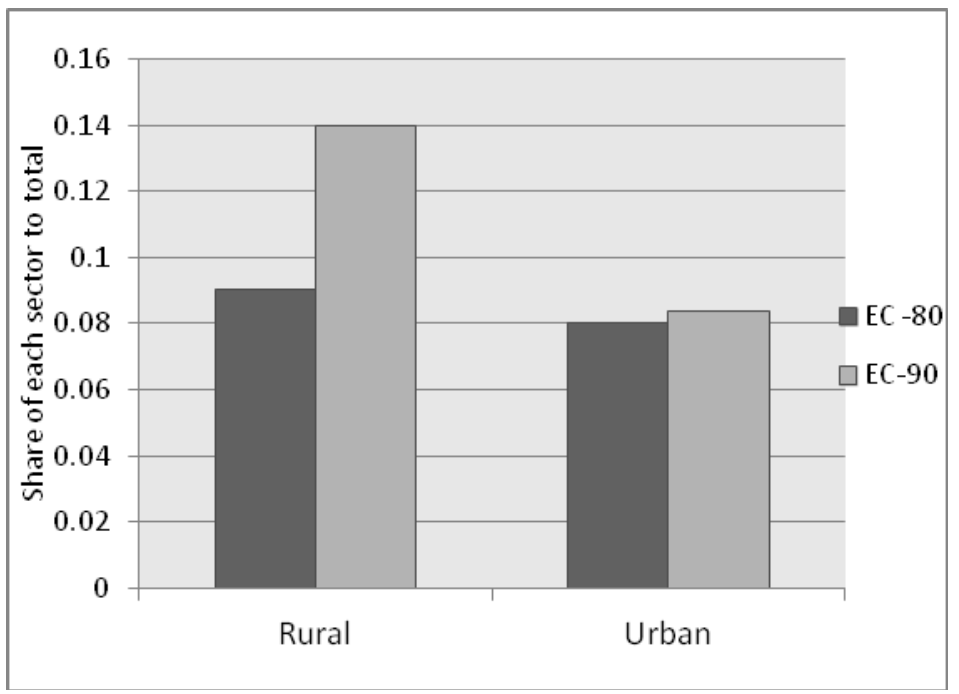

C. Andhra Pradesh

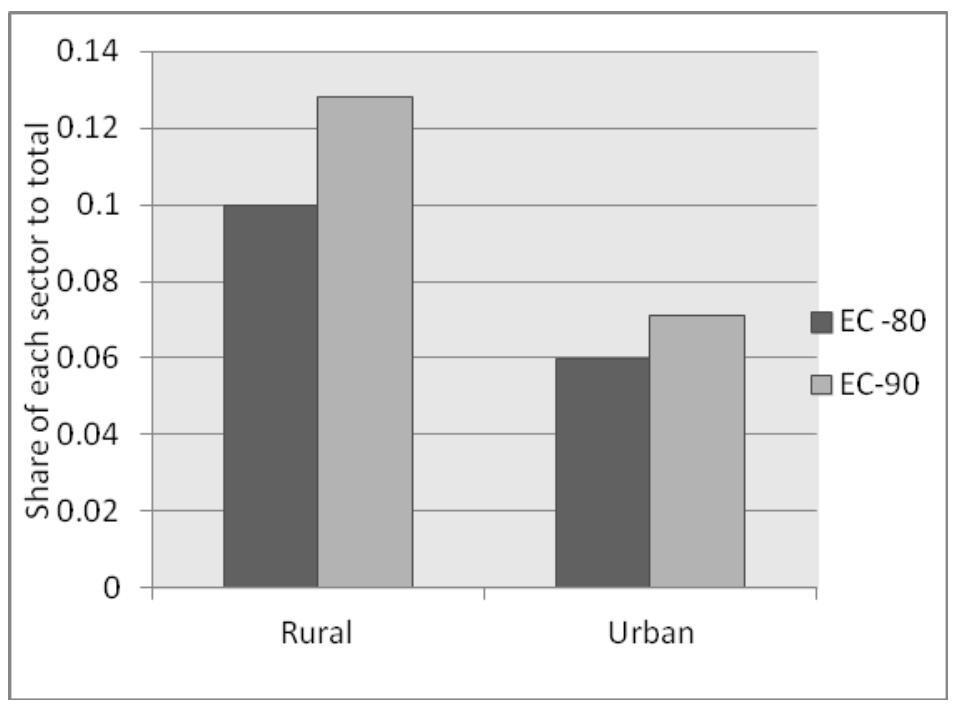

B. Maharashtra

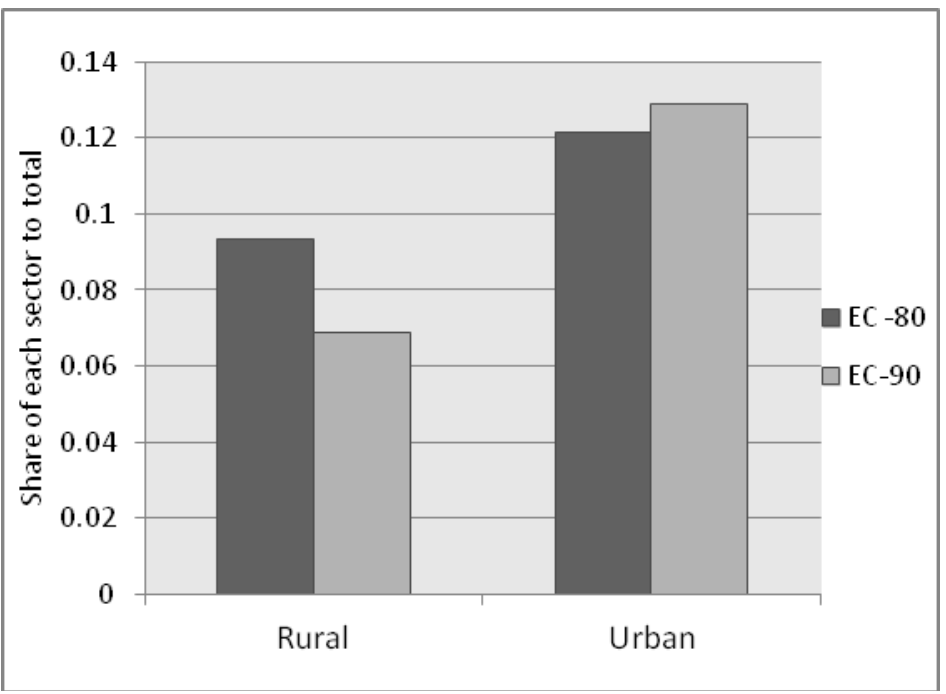

D. Kerala

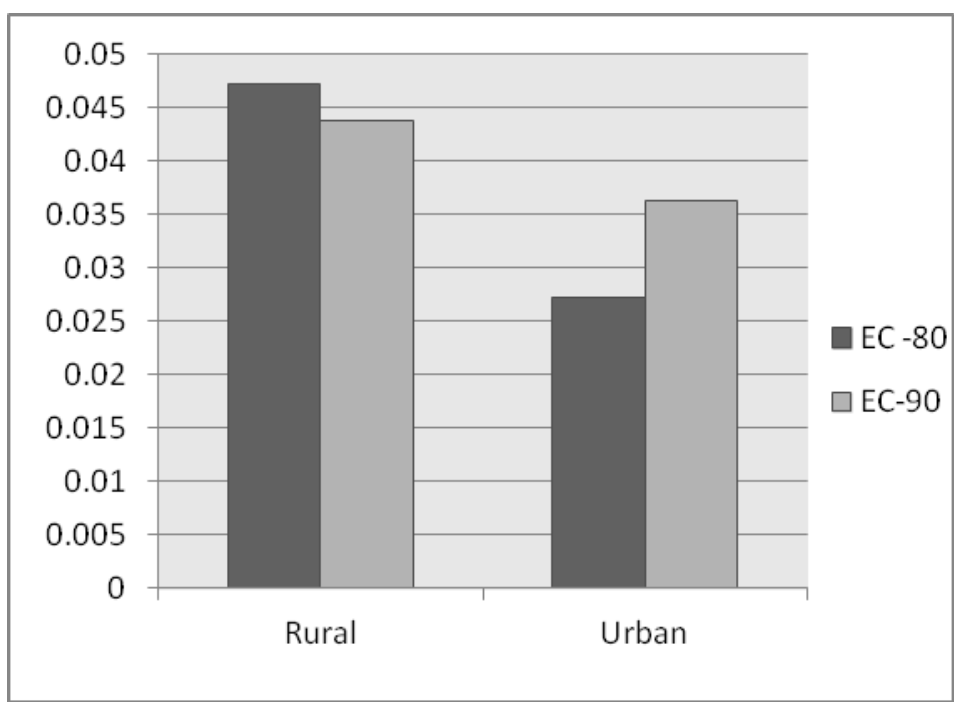


Figure 3: Association between Corruption and Informal Sector, 2004-2005

\section{A. Total (Urban +Rural)}

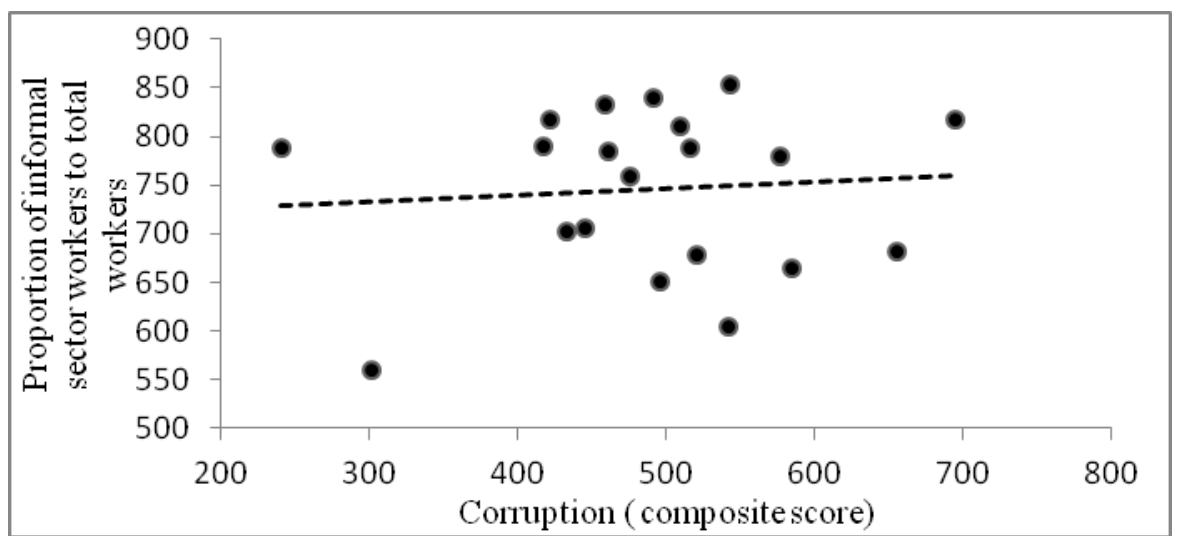

\section{B. Urban}

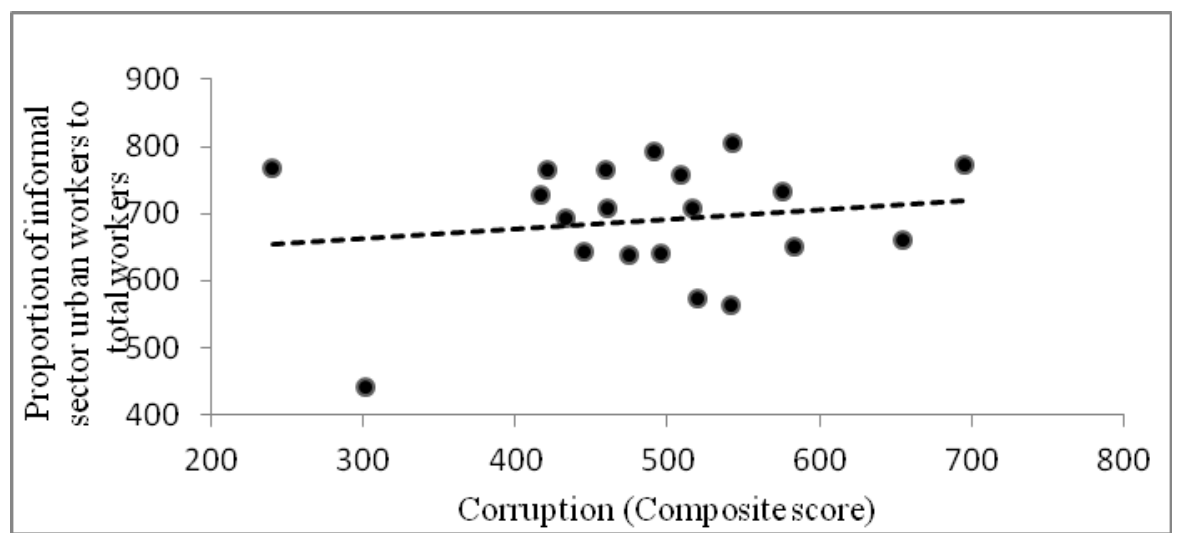

\section{B. Rural}

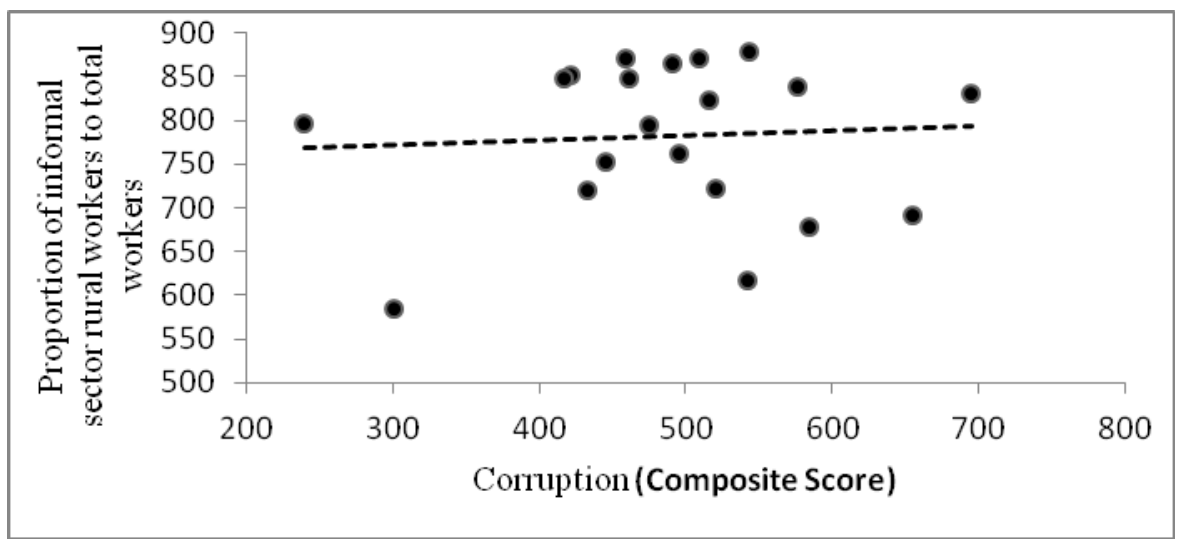


Table 1: Impact of Corruption on Informal Sector

\begin{tabular}{l|ccc}
\hline & $(1)$ & $(2)$ & $(3)$ \\
Independent Variables & Rural + Urban & Urban & Rural \\
\hline \multirow{3}{*}{ Corruption } & $0.283^{*}$ & $0.562^{* * *}$ & 0.207 \\
SDP & $(0.153)$ & $(0.179)$ & $(0.174)$ \\
& $0.00605^{* * *}$ & $0.00836^{* * *}$ & $0.00598^{* * *}$ \\
SDP sq & $(0.00154)$ & $(0.00218)$ & $(0.00169)$ \\
& $-1.67 \mathrm{e}-08^{* * *}$ & $-1.79 \mathrm{e}-08^{* * *}$ & $-1.89 \mathrm{e}-08^{* * *}$ \\
SDP*Corruption & $(2.75 \mathrm{e}-09)$ & $(3.56 \mathrm{e}-09)$ & $(2.88 \mathrm{e}-09)$ \\
& $-4.30 \mathrm{e}-06$ & $-8.27 \mathrm{e}-06^{* *}$ & $-3.10 \mathrm{e}-06$ \\
Constant & $(2.77 \mathrm{e}-06)$ & $(3.58 \mathrm{e}-06)$ & $(2.94 \mathrm{e}-06)$ \\
& $444.7^{* * *}$ & $233.0^{* *}$ & $499.8^{* * *}$ \\
& $(82.09)$ & $(98.85)$ & $(99.03)$ \\
\hline Observations & & & 20 \\
R-squared & 20 & 20 & 0.630 \\
\hline
\end{tabular}

Robust standard errors in parentheses

*** $\mathrm{p}<0.01,{ }^{* *} \mathrm{p}<0.05,{ }^{*} \mathrm{p}<0.1$ 
Table 2: Impact of Corruption on Informal Sector - Inclusion of HDI

\begin{tabular}{l|ccc}
\hline & $(1)$ & $(2)$ & $(3)$ \\
Independent Variables & Rural + Urban & Urban & Rural \\
\hline & & & \\
Corruption & 0.240 & $0.562^{* *}$ & 0.197 \\
SDP & $(0.157)$ & $(0.190)$ & $(0.178)$ \\
& $0.00667^{* * *}$ & $0.00837^{* * *}$ & $0.00612^{* * *}$ \\
SDP sq & $(0.00162)$ & $(0.00220)$ & $(0.00167)$ \\
& $-1.76 \mathrm{e}-08^{* * *}$ & $-1.79 \mathrm{e}-08^{* * *}$ & $-1.91 \mathrm{e}-08^{* * *}$ \\
SDP*Corruption & $(2.88 \mathrm{e}-09)$ & $(3.61 \mathrm{e}-09)$ & $(2.92 \mathrm{e}-09)$ \\
& $-5.22 \mathrm{e}-06^{*}$ & $-8.28 \mathrm{e}-06^{* *}$ & $-3.31 \mathrm{e}-06$ \\
HDI & $(2.91 \mathrm{e}-06)$ & $(3.61 \mathrm{e}-06)$ & $(2.96 \mathrm{e}-06)$ \\
& -195.1 & -2.427 & -43.87 \\
Constant & $(178.0)$ & $(172.4)$ & $(131.0)$ \\
& $540.7^{* * *}$ & 234.2 & $521.4^{* * *}$ \\
& $(116.0)$ & $(138.2)$ & $(124.4)$ \\
\hline Observations & & & 20 \\
R-squared & 20 & 20 & 0.631 \\
\hline
\end{tabular}

Robust standard errors in parentheses

*** $\mathrm{p}<0.01,{ }^{* *} \mathrm{p}<0.05,{ }^{*} \mathrm{p}<0.1$ 
Table 3: Impact of Corruption on Informal Sector - 2SLS specifications

\begin{tabular}{|c|c|c|c|c|c|c|}
\hline \multirow[b]{2}{*}{ Independent } & \multicolumn{3}{|c|}{ IV } & \multicolumn{3}{|c|}{ GMM } \\
\hline & $\begin{array}{c}\text { (1) } \\
\text { Rural + Urban } \\
\end{array}$ & $\begin{array}{c}(2) \\
\text { Urban } \\
\end{array}$ & $\begin{array}{c}(3) \\
\text { Rural } \\
\end{array}$ & $\begin{array}{c}\text { (4) } \\
\text { Rural + Urban }\end{array}$ & $\begin{array}{c}5) \\
\text { Urban } \\
\end{array}$ & $\begin{array}{c}(6) \\
\text { Rural } \\
\end{array}$ \\
\hline Corruption & $\begin{array}{c}0.523 \\
(0.350)\end{array}$ & $\begin{array}{l}0.569 * \\
(0.300)\end{array}$ & $\begin{array}{c}0.598 \\
(0.407)\end{array}$ & $\begin{array}{c}0.433 \\
(0.341)\end{array}$ & $\begin{array}{l}0.575^{*} \\
(0.300)\end{array}$ & $\begin{array}{c}0.478 \\
(0.378)\end{array}$ \\
\hline SDP & $\begin{array}{c}0.00879 * * * \\
(0.00302)\end{array}$ & $\begin{array}{c}0.00843^{* * *} \\
(0.00246)\end{array}$ & $\begin{array}{c}0.00914 * * * \\
(0.00333)\end{array}$ & $\begin{array}{l}-8.39 \mathrm{e}-06 \\
(5.74 \mathrm{e}-06)\end{array}$ & $\begin{array}{c}-8.75 \mathrm{e}-06^{* *} \\
(4.46 \mathrm{e}-06)\end{array}$ & $\begin{array}{l}-7.47 \mathrm{e}-06 \\
(6.21 \mathrm{e}-06)\end{array}$ \\
\hline SDP sq & $\begin{array}{c}-1.87 \mathrm{e}-08^{* * * *} \\
(2.73 \mathrm{e}-09)\end{array}$ & $\begin{array}{c}-1.80 \mathrm{e}-08^{* * *} \\
(3.00 \mathrm{e}-09)\end{array}$ & $\begin{array}{c}-2.07 \mathrm{e}-08 * * * \\
(2.81 \mathrm{e}-09)\end{array}$ & $\begin{array}{c}0.00830 * * * \\
(0.00299)\end{array}$ & $\begin{array}{c}0.00853 * * * \\
(0.00246)\end{array}$ & $\begin{array}{c}0.00825^{* * * *} \\
(0.00313)\end{array}$ \\
\hline SDP*Corruption & $\begin{array}{l}--0.00001 \\
(0.00001)\end{array}$ & $\begin{array}{l}-0.00001^{*} \\
(0.000004)\end{array}$ & $\begin{array}{l}--0.00001 \\
(0.00001)\end{array}$ & $\begin{array}{c}-1.89 \mathrm{e}-08 * * * \\
(2.73 \mathrm{e}-09)\end{array}$ & $\begin{array}{c}-1.80 \mathrm{e}-08 * * * \\
(3.00 \mathrm{e}-09)\end{array}$ & $\begin{array}{c}-2.06 \mathrm{e}-08 * * * \\
(2.81 \mathrm{e}-09)\end{array}$ \\
\hline HDI & $\begin{array}{l}-164.7 \\
(182.3)\end{array}$ & $\begin{array}{l}-1.635 \\
(150.1)\end{array}$ & $\begin{array}{l}-0.713 \\
(159.6)\end{array}$ & $\begin{array}{l}-218.5 \\
(176.2)\end{array}$ & $\begin{array}{l}-46.22 \\
(147.0)\end{array}$ & $\begin{array}{l}-40.81 \\
(151.4)\end{array}$ \\
\hline Constant & $\begin{array}{l}387.7^{*} \\
(228.2)\end{array}$ & $\begin{array}{c}230.2 \\
(186.9)\end{array}$ & $\begin{array}{c}304.2 \\
(263.7)\end{array}$ & $\begin{array}{l}460.1^{* *} \\
(219.4)\end{array}$ & $\begin{array}{c}250.8 \\
(186.3)\end{array}$ & $\begin{array}{c}388.5 \\
(241.3)\end{array}$ \\
\hline Observations & 20 & 20 & 20 & 20 & 20 & 20 \\
\hline R-squared & 0.564 & 0.678 & 0.575 & 0.574 & 0.674 & 0.598 \\
\hline Sargan Statistic & $\begin{array}{c}1.16 \\
(p=0.28)\end{array}$ & $\begin{array}{c}2.29 \\
(p=0.13)\end{array}$ & $\begin{array}{c}0.49 \\
(p=0.48)\end{array}$ & --- & --- & --- \\
\hline Hansen J Statistic & -- & -- & -- & $\begin{array}{c}1.33 \\
(p=0.25)\end{array}$ & $\begin{array}{c}2.17 \\
(p=0.14)\end{array}$ & $\begin{array}{c}0.63 \\
(p=0.43)\end{array}$ \\
\hline
\end{tabular}

Robust standard errors in parentheses

$* * * \mathrm{p}<0.01, * * \mathrm{p}<0.05,{ }^{*} \mathrm{p}<0.1$ 
Table 4: Impact of Corruption on Informal Sector - Considering Sector Wise Corruption (Urban + Rural)

\begin{tabular}{|c|c|c|c|c|c|c|c|c|c|c|c|}
\hline & \multicolumn{6}{|c|}{ Need Based } & \multicolumn{5}{|c|}{ Basic } \\
\hline & $\begin{array}{c}\text { Rural } \\
\text { Financial } \\
\text { Services } \\
(1) \\
\end{array}$ & Income Tax & $\begin{array}{l}\text { Municipal } \\
\text { Services } \\
\text { (3) }\end{array}$ & Judiciary & $\begin{array}{c}\text { Land } \\
\text { Administration } \\
\text { (5) }\end{array}$ & $\begin{array}{c}\text { Police } \\
(6) \\
\end{array}$ & $\begin{array}{l}\text { School } \\
\text { (7) }\end{array}$ & $\begin{array}{l}\text { Water } \\
\text { Supply } \\
\text { (8) }\end{array}$ & $\begin{array}{c}\text { PDS/Ration } \\
\text { (9) } \\
\end{array}$ & $\begin{array}{c}\text { Electricity } \\
(10) \\
\end{array}$ & $\begin{array}{c}\text { Government } \\
\text { Hospitals } \\
\text { (11) }\end{array}$ \\
\hline SDP & $\begin{array}{c}0.00404^{* * *} \\
(0.00107)\end{array}$ & $\begin{array}{c}0.00420 * * \\
(0.00149)\end{array}$ & $\begin{array}{c}0.00521 * * * \\
(0.000675)\end{array}$ & $\begin{array}{c}0.00573 * * * \\
(0.00165)\end{array}$ & $\begin{array}{c}0.00456 \\
(0.00275)\end{array}$ & $\begin{array}{c}0.00258 \\
(0.00419)\end{array}$ & $\begin{array}{c}0.00417 * * * \\
(0.000933)\end{array}$ & $\begin{array}{c}0.00489 * * * \\
(0.00112)\end{array}$ & $\begin{array}{c}0.00596 * * * \\
(0.00113)\end{array}$ & $\begin{array}{c}0.00387^{* * *} \\
(0.00102)\end{array}$ & $\begin{array}{c}0.00573 * * * \\
(0.00119)\end{array}$ \\
\hline SDP sq & $\begin{array}{c}-1.48 \mathrm{e}- \\
08 * * * \\
(3.26 \mathrm{e}-09)\end{array}$ & $\begin{array}{c}-1.58 \mathrm{e}- \\
08^{* * *} \\
(3.92 \mathrm{e}-09)\end{array}$ & $\begin{array}{c}-1.41 \mathrm{e}- \\
08 * * * \\
(2.81 \mathrm{e}-09)\end{array}$ & $\begin{array}{c}-1.68 \mathrm{e}- \\
08 * * * \\
(3.27 \mathrm{e}-09)\end{array}$ & $\begin{array}{c}-1.57 \mathrm{e}-08^{* *} \\
(5.39 \mathrm{e}-09)\end{array}$ & $\begin{array}{c}-1.46 \mathrm{e}- \\
08^{* * *} \\
(4.00 \mathrm{e}-09)\end{array}$ & $\begin{array}{c}-1.50 \mathrm{e}- \\
08 * * * \\
(3.09 \mathrm{e}-09)\end{array}$ & $\begin{array}{c}-1.67 e- \\
08 * * * \\
(3.33 e-09)\end{array}$ & $\begin{array}{c}-1.93 \mathrm{e}- \\
08 * * * \\
(2.84 \mathrm{e}-09)\end{array}$ & $\begin{array}{c}-1.53 \mathrm{e}- \\
08 * * * \\
(2.83 \mathrm{e}-09)\end{array}$ & $\begin{array}{c}-1.52 \mathrm{e}- \\
08^{* * *} \\
(3.13 \mathrm{e}-09)\end{array}$ \\
\hline Corruption & $\begin{array}{c}1.063 \\
(2.889)\end{array}$ & $\begin{array}{c}0.790 \\
(1.920)\end{array}$ & $\begin{array}{c}2.633^{* * * *} \\
(0.852)\end{array}$ & $\begin{array}{c}2.101 \\
(1.504)\end{array}$ & $\begin{array}{c}1.771 \\
(2.296)\end{array}$ & $\begin{array}{l}-0.181 \\
(4.143)\end{array}$ & $\begin{array}{c}2.733 \\
(2.658)\end{array}$ & $\begin{array}{c}1.214 \\
(1.641)\end{array}$ & $\begin{array}{l}2.145^{* *} \\
(0.866)\end{array}$ & $\begin{array}{c}1.393 \\
(1.617)\end{array}$ & $\begin{array}{c}4.196^{* *} \\
(1.564)\end{array}$ \\
\hline Interaction & $\begin{array}{l}-1.32 e-05 \\
(3.55 e-05)\end{array}$ & $\begin{array}{l}-8.43 e-06 \\
(2.11 \mathrm{e}-05)\end{array}$ & $\begin{array}{c}-3.12 \mathrm{e}- \\
05^{* * *} \\
(9.55 \mathrm{e}-06)\end{array}$ & $\begin{array}{l}-2.73 e-05 \\
(1.98 e-05)\end{array}$ & $\begin{array}{l}-1.11 \mathrm{e}-05 \\
(2.97 \mathrm{e}-05)\end{array}$ & $\begin{array}{l}1.77 \mathrm{e}-05 \\
(5.78 \mathrm{e}-05)\end{array}$ & $\begin{array}{l}-1.92 \mathrm{e}-05 \\
(3.56 \mathrm{e}-05)\end{array}$ & $\begin{array}{l}-2.35 e-05 \\
(1.48 e-05)\end{array}$ & $\begin{array}{l}-4.53 e-05 * \\
(2.21 \mathrm{e}-05)\end{array}$ & $\begin{array}{l}-1.74 \mathrm{e}-06 \\
(1.98 \mathrm{e}-05)\end{array}$ & $\begin{array}{c}-5.40 \mathrm{e}-05^{* *} \\
(2.34 \mathrm{e}-05)\end{array}$ \\
\hline Constant & $\begin{array}{c}560.7 * * * \\
(88.37)\end{array}$ & $\begin{array}{c}553.3 * * * \\
(94.53)\end{array}$ & $\begin{array}{c}456.4^{* * *} \\
(53.19)\end{array}$ & $\begin{array}{c}444.3^{* * *} \\
(120.4)\end{array}$ & $\begin{array}{l}471.0 * * \\
(171.2)\end{array}$ & $\begin{array}{l}596.9 * \\
(295.4)\end{array}$ & $\begin{array}{c}525.1^{* * *} \\
(69.27)\end{array}$ & $\begin{array}{c}535.1^{* * *} \\
(76.82)\end{array}$ & $\begin{array}{c}495.4^{* * *} \\
(50.51)\end{array}$ & $\begin{array}{c}530.5^{* * *} \\
(72.68)\end{array}$ & $\begin{array}{c}438.2 * * * \\
(48.41)\end{array}$ \\
\hline Observations & 20 & 20 & 20 & 20 & 20 & 20 & 20 & 20 & 20 & 20 & 20 \\
\hline R-squared & 0.537 & 0.538 & 0.594 & 0.556 & 0.556 & 0.538 & 0.566 & 0.569 & 0.576 & 0.563 & 0.588 \\
\hline
\end{tabular}

Robust standard errors in parentheses

$$
* * * \mathrm{p}<0.01,{ }^{* *} \mathrm{p}<0.05, * \mathrm{p}<0.1
$$


Table 5: Impact of Corruption on Informal Sector - Considering Sector Wise Corruption (Urban)

\begin{tabular}{|c|c|c|c|c|c|c|c|c|c|c|c|}
\hline VARIABLES & $\begin{array}{c}\text { Rural } \\
\text { Financial } \\
\text { Services } \\
(1) \\
\end{array}$ & Income Tax & $\begin{array}{c}\text { Municipal } \\
\text { Services } \\
\text { (3) } \\
\end{array}$ & Judiciary & $\begin{array}{c}\text { Land } \\
\text { Administration } \\
\text { (5) }\end{array}$ & Police & School & $\begin{array}{c}\text { Water } \\
\text { Supply } \\
\text { (8) }\end{array}$ & PDS/Ration & Electricity & $\begin{array}{c}\text { Government } \\
\text { Hospitals } \\
(11) \\
\end{array}$ \\
\hline SDP & $\begin{array}{c}0.00428 * * \\
(0.00147)\end{array}$ & $\begin{array}{c}0.00534 * * \\
(0.00204)\end{array}$ & $\begin{array}{c}0.00604 * * * \\
(0.00114)\end{array}$ & $\begin{array}{c}0.00654 * * \\
(0.00294)\end{array}$ & $\begin{array}{l}0.00739 * \\
(0.00381)\end{array}$ & $\begin{array}{c}0.00547 \\
(0.00556)\end{array}$ & $\begin{array}{c}0.00498 * * * \\
(0.00144)\end{array}$ & $\begin{array}{c}0.00606 * * * \\
(0.00139)\end{array}$ & $\begin{array}{c}0.00781 * * * \\
(0.00151)\end{array}$ & $\begin{array}{c}0.00507 * * * \\
(0.00138)\end{array}$ & $\begin{array}{c}0.00721 * * * \\
(0.00183)\end{array}$ \\
\hline SDP sq & $\begin{array}{c}-1.49 \mathrm{e}-08^{* * *} \\
(4.64 \mathrm{e}-09)\end{array}$ & $\begin{array}{c}-1.68 \mathrm{e}-08 * * * \\
(5.05 \mathrm{e}-09)\end{array}$ & $\begin{array}{c}-1.38 \mathrm{e}-08 * * * \\
(3.19 \mathrm{e}-09)\end{array}$ & $\begin{array}{c}-1.73 \mathrm{e}-08^{* * *} \\
(4.93 \mathrm{e}-09)\end{array}$ & $\begin{array}{c}-1.90 \mathrm{e}-08 * * \\
(7.26 \mathrm{e}-09)\end{array}$ & $\begin{array}{c}-1.63 \mathrm{e}-08^{* * *} \\
(5.54 \mathrm{e}-09)\end{array}$ & $\begin{array}{c}-1.44 \mathrm{e}-08 * * * \\
(3.78 \mathrm{e}-09)\end{array}$ & $\begin{array}{c}-1.79 \mathrm{e}-08^{* * *} \\
(4.01 \mathrm{e}-09)\end{array}$ & $\begin{array}{c}-2.21 \mathrm{e}- \\
08 * * * \\
(3.77 \mathrm{e}-09)\end{array}$ & $\begin{array}{c}-1.57 \mathrm{e}- \\
08 * * * \\
(3.27 \mathrm{e}-09)\end{array}$ & $\begin{array}{c}-1.55 \mathrm{e}- \\
08 * * * \\
(4.17 \mathrm{e}-09)\end{array}$ \\
\hline Corruption & $\begin{array}{c}1.847 \\
(3.709)\end{array}$ & $\begin{array}{c}2.699 \\
(2.429)\end{array}$ & $\begin{array}{c}3.910^{* * *} \\
(1.294)\end{array}$ & $\begin{array}{c}2.633 \\
(2.785)\end{array}$ & $\begin{array}{c}4.193 \\
(3.100)\end{array}$ & $\begin{array}{c}3.247 \\
(4.926)\end{array}$ & $\begin{array}{c}5.246 \\
(3.776)\end{array}$ & $\begin{array}{c}2.778 \\
(2.308)\end{array}$ & $\begin{array}{c}4.569 * * * \\
(0.873)\end{array}$ & $\begin{array}{l}3.537^{*} \\
(1.880)\end{array}$ & $\begin{array}{c}6.390 * * * \\
(1.962)\end{array}$ \\
\hline Interaction & $\begin{array}{l}-1.28 \mathrm{e}-05 \\
(4.69 \mathrm{e}-05)\end{array}$ & $\begin{array}{l}-2.78 \mathrm{e}-05 \\
(2.81 \mathrm{e}-05)\end{array}$ & $\begin{array}{c}-4.43 \mathrm{e}-05^{* * * *} \\
(1.31 \mathrm{e}-05)\end{array}$ & $\begin{array}{l}-3.54 \mathrm{e}-05 \\
(3.50 \mathrm{e}-05)\end{array}$ & $\begin{array}{l}-4.42 \mathrm{e}-05 \\
(4.23 \mathrm{e}-05)\end{array}$ & $\begin{array}{l}-1.76 \mathrm{e}-05 \\
(7.45 \mathrm{e}-05)\end{array}$ & $\begin{array}{l}-4.93 e-05 \\
(5.08 \mathrm{e}-05)\end{array}$ & $\begin{array}{c}-4.37 \mathrm{e}-05^{*} \\
(2.06 \mathrm{e}-05)\end{array}$ & $\begin{array}{c}-7.93 e-05 * * \\
(2.83 e-05)\end{array}$ & $\begin{array}{c}-2.50 \mathrm{e}-05 \\
(2.51 \mathrm{e}-05)\end{array}$ & $\begin{array}{c}-8.66 \mathrm{e}-05 * * \\
(3.27 \mathrm{e}-05)\end{array}$ \\
\hline Constant & $\begin{array}{c}465.1^{* * *} \\
(115.2)\end{array}$ & $\begin{array}{c}402.6^{* * *} \\
(124.9)\end{array}$ & $\begin{array}{c}321.0 * * * \\
(85.38)\end{array}$ & $\begin{array}{c}336.6 \\
(211.1)\end{array}$ & $\begin{array}{c}232.0 \\
(229.5)\end{array}$ & $\begin{array}{c}281.6 \\
(352.5)\end{array}$ & $\begin{array}{c}398.8 * * * \\
(99.59)\end{array}$ & $\begin{array}{c}401.3^{* * *} \\
(97.72)\end{array}$ & $\begin{array}{c}322.9 * * * \\
(52.69)\end{array}$ & $\begin{array}{c}372.7 * * * \\
(85.21)\end{array}$ & $\begin{array}{c}287.0 * * * \\
(80.28)\end{array}$ \\
\hline $\begin{array}{l}\text { Observations } \\
\text { R-squared }\end{array}$ & $\begin{array}{c}20 \\
0.597\end{array}$ & $\begin{array}{c}20 \\
0.616\end{array}$ & $\begin{array}{c}20 \\
0.687\end{array}$ & $\begin{array}{c}20 \\
0.604\end{array}$ & $\begin{array}{c}20 \\
0.637\end{array}$ & $\begin{array}{c}20 \\
0.612\end{array}$ & $\begin{array}{c}20 \\
0.643\end{array}$ & $\begin{array}{c}20 \\
0.666\end{array}$ & $\begin{array}{c}20 \\
0.721\end{array}$ & $\begin{array}{c}20 \\
0.665\end{array}$ & $\begin{array}{c}20 \\
0.680\end{array}$ \\
\hline
\end{tabular}

Robust standard errors in parentheses

$* * * \mathrm{p}<0.01, * * \mathrm{p}<0.05, * \mathrm{p}<0.1$ 
Table 6: Impact of Corruption on Informal Sector - Considering Sector Wise Corruption (Rural)

\begin{tabular}{|c|c|c|c|c|c|c|c|c|c|c|c|}
\hline VARIABLES & (1) & (2) & (3) & (4) & (5) & (6) & (7) & (8) & (9) & (10) & (11) \\
\hline SDP & $\begin{array}{c}0.00487 * * * \\
(0.000930)\end{array}$ & $\begin{array}{c}0.00439 * * \\
(0.00154)\end{array}$ & $\begin{array}{c}0.00524 * * * \\
(0.000789)\end{array}$ & $\begin{array}{c}0.00554 * * * \\
(0.00169)\end{array}$ & $\begin{array}{l}0.00495 * \\
(0.00260)\end{array}$ & $\begin{array}{c}0.00359 \\
(0.00413)\end{array}$ & $\begin{array}{c}0.00465 * * * \\
(0.000904)\end{array}$ & $\begin{array}{c}0.00507^{* * *} \\
(0.00128)\end{array}$ & $\begin{array}{c}0.00541^{* * *} \\
(0.00110)\end{array}$ & $\begin{array}{c}0.00452^{* * *} \\
(0.00115)\end{array}$ & $\begin{array}{c}0.00643 * * * \\
(0.00102)\end{array}$ \\
\hline SDP sq & $\begin{array}{c}-1.67 \mathrm{e}-08 * * * \\
(3.13 \mathrm{e}-09)\end{array}$ & $\begin{array}{c}-1.81 \mathrm{e}-08 * * * \\
(4.00 \mathrm{e}-09)\end{array}$ & $\begin{array}{c}-1.72 \mathrm{e}-08 * * * \\
(2.92 \mathrm{e}-09)\end{array}$ & $\begin{array}{c}-1.89 \mathrm{e}-08 * * * \\
(3.46 \mathrm{e}-09)\end{array}$ & $\begin{array}{c}-1.83 \mathrm{e}-08 * * * \\
(5.10 \mathrm{e}-09)\end{array}$ & $\begin{array}{c}-1.75 \mathrm{e}-08 * * * \\
(4.08 \mathrm{e}-09)\end{array}$ & $\begin{array}{c}-1.77 \mathrm{e}-08^{* * *} \\
(3.11 \mathrm{e}-09)\end{array}$ & $\begin{array}{c}-1.89 \mathrm{e}-08 * * * \\
(3.58 \mathrm{e}-09)\end{array}$ & $\begin{array}{c}-1.97 \mathrm{e}-08 * * * \\
(3.06 \mathrm{e}-09)\end{array}$ & $\begin{array}{c}-1.80 \mathrm{e}-08 * * * \\
(3.01 \mathrm{e}-09)\end{array}$ & $\begin{array}{c}-1.84 \mathrm{e}-08 * * * \\
(2.75 \mathrm{e}-09)\end{array}$ \\
\hline Corruption & $\begin{array}{c}2.280 \\
(2.177)\end{array}$ & $\begin{array}{l}0.0286 \\
(1.961)\end{array}$ & $\begin{array}{l}1.961^{* *} \\
(0.874)\end{array}$ & $\begin{array}{c}1.507 \\
(1.413)\end{array}$ & $\begin{array}{c}1.346 \\
(2.126)\end{array}$ & $\begin{array}{l}-0.603 \\
(4.341)\end{array}$ & $\begin{array}{c}2.184 \\
(2.351)\end{array}$ & $\begin{array}{c}0.533 \\
(1.852)\end{array}$ & $\begin{array}{c}1.576 \\
(0.948)\end{array}$ & $\begin{array}{c}0.814 \\
(1.822)\end{array}$ & $\begin{array}{l}3.470^{*} \\
(1.796)\end{array}$ \\
\hline Interaction & $\begin{array}{c}-2.92 \mathrm{e}-05 \\
(2.99 \mathrm{e}-05)\end{array}$ & $\begin{array}{l}-5.27 e-07 \\
(2.06 e-05)\end{array}$ & $\begin{array}{l}-1.96 \mathrm{e}-05^{*} \\
(1.02 \mathrm{e}-05)\end{array}$ & $\begin{array}{l}-1.62 \mathrm{e}-05 \\
(1.94 \mathrm{e}-05)\end{array}$ & $\begin{array}{l}-8.56 \mathrm{e}-06 \\
(2.63 \mathrm{e}-05)\end{array}$ & $\begin{array}{c}1.07 \mathrm{e}-05 \\
(5.59 \mathrm{e}-05)\end{array}$ & $\begin{array}{c}-1.51 \mathrm{e}-05 \\
(3.20 \mathrm{e}-05)\end{array}$ & $\begin{array}{l}-1.50 \mathrm{e}-05 \\
(1.72 \mathrm{e}-05)\end{array}$ & $\begin{array}{c}-2.22 \mathrm{e}-05 \\
(1.82 \mathrm{e}-05)\end{array}$ & $\begin{array}{c}-3.87 e-06 \\
(2.13 e-05)\end{array}$ & $\begin{array}{c}-5.39 \mathrm{e}-05 * * \\
(2.34 \mathrm{e}-05)\end{array}$ \\
\hline Constant & $\begin{array}{c}549.1^{* * *} \\
(74.97)\end{array}$ & $\begin{array}{c}601.8^{* * * *} \\
(101.0)\end{array}$ & $\begin{array}{c}505.7 * * * \\
(59.90)\end{array}$ & $\begin{array}{c}500.4^{* * *} \\
(117.8)\end{array}$ & $\begin{array}{c}515.5^{* * *} \\
(169.1)\end{array}$ & $\begin{array}{l}645.3^{*} \\
(312.8)\end{array}$ & $\begin{array}{c}554.3 * * * \\
(65.36)\end{array}$ & $\begin{array}{c}578.8 * * * \\
(89.73)\end{array}$ & $\begin{array}{c}537.9 * * * \\
(59.94)\end{array}$ & $\begin{array}{c}570.6^{* * *} \\
(86.02)\end{array}$ & $\begin{array}{c}477.1^{* * * *} \\
(55.25)\end{array}$ \\
\hline Observations & 20 & 20 & 20 & 20 & 20 & 20 & 20 & 20 & 20 & 20 & 20 \\
\hline R-squared & 0.630 & 0.615 & 0.647 & 0.626 & 0.626 & 0.615 & 0.634 & 0.632 & 0.634 & 0.621 & 0.650 \\
\hline
\end{tabular}

Robust standard errors in parentheses

$*_{* *} \mathrm{p}<0.01, * * \mathrm{p}<0.05,{ }^{*} \mathrm{p}<0.1$ 
Table 7: Impact of Corruption on Informal Employment for Different Industries in Urban and Rural Areas

\begin{tabular}{|c|c|c|c|c|c|c|c|c|c|}
\hline \multirow[b]{2}{*}{ Independent Variables } & \multicolumn{3}{|c|}{ Manufacturing } & \multicolumn{3}{|c|}{ Construction } & \multicolumn{3}{|c|}{ Education } \\
\hline & $\begin{array}{c}\text { Total } \\
(1) \\
\end{array}$ & $\begin{array}{l}\text { Urban } \\
(2)\end{array}$ & $\begin{array}{c}\text { Rural } \\
(3) \\
\end{array}$ & $\begin{array}{c}\text { Total } \\
(4) \\
\end{array}$ & $\begin{array}{c}\text { Urban } \\
(5)\end{array}$ & $\begin{array}{c}\text { Rural } \\
(6) \\
\end{array}$ & $\begin{array}{c}\text { Total } \\
(7) \\
\end{array}$ & $\begin{array}{c}\text { Urban } \\
(8)\end{array}$ & $\begin{array}{c}\text { Rural } \\
(9) \\
\end{array}$ \\
\hline SDP & $\begin{array}{c}0.00830 * * \\
(0.00327)\end{array}$ & $\begin{array}{c}0.0191 * * * \\
(0.00421)\end{array}$ & $\begin{array}{c}0.00405 \\
(0.00627)\end{array}$ & $\begin{array}{c}0.0114^{* * *} \\
(0.00346)\end{array}$ & $\begin{array}{l}0.0123^{* *} \\
(0.00546)\end{array}$ & $\begin{array}{c}0.00996 * * \\
(0.00362)\end{array}$ & $\begin{array}{c}0.00771 \\
(0.00567)\end{array}$ & $\begin{array}{c}0.00622 \\
(0.00600)\end{array}$ & $\begin{array}{c}0.00945 \\
(0.00584)\end{array}$ \\
\hline SDP sq & $\begin{array}{c}-1.42 \mathrm{e}-08^{* *} \\
(5.78 \mathrm{e}-09)\end{array}$ & $\begin{array}{c}-2.87 \mathrm{e}-08 * * * \\
(7.56 \mathrm{e}-09)\end{array}$ & $\begin{array}{c}-1.37 e-08 \\
(8.69 e-09)\end{array}$ & $\begin{array}{c}-2.56 \mathrm{e}-08 * * * \\
(5.27 \mathrm{e}-09)\end{array}$ & $\begin{array}{c}-2.31 \mathrm{e}-08 * * * \\
(7.63 \mathrm{e}-09)\end{array}$ & $\begin{array}{c}-2.99 \mathrm{e}-08 * * * \\
(5.63 \mathrm{e}-09)\end{array}$ & $\begin{array}{c}-1.98 \mathrm{e}-08 * \\
(9.66 \mathrm{e}-09)\end{array}$ & $\begin{array}{c}-1.48 \mathrm{e}-08 \\
(9.94 \mathrm{e}-09)\end{array}$ & $\begin{array}{c}-2.39 \mathrm{e}-08 * * \\
(1.02 \mathrm{e}-08)\end{array}$ \\
\hline Corruption & $\begin{array}{c}0.872^{* *} \\
(0.303)\end{array}$ & $\begin{array}{c}2.243 * * * \\
(0.452)\end{array}$ & $\begin{array}{l}-0.930 \\
(0.916)\end{array}$ & $\begin{array}{c}0.327 \\
(0.401)\end{array}$ & $\begin{array}{c}0.379 \\
(0.675)\end{array}$ & $\begin{array}{c}0.470 \\
(0.504)\end{array}$ & $\begin{array}{c}0.129 \\
(0.296)\end{array}$ & $\begin{array}{l}-0.0152 \\
(0.454)\end{array}$ & $\begin{array}{c}0.110 \\
(0.285)\end{array}$ \\
\hline SDP*Corruption & $\begin{array}{c}-1.09 \mathrm{e}-05^{*} \\
(5.40 \mathrm{e}-06)\end{array}$ & $\begin{array}{c}-2.56 \mathrm{e}-05 * * * \\
(7.29 \mathrm{e}-06)\end{array}$ & $\begin{array}{c}-2.07 e-06 \\
(1.19 e-05)\end{array}$ & $\begin{array}{l}-1.04 \mathrm{e}-05^{*} \\
(5.44 \mathrm{e}-06)\end{array}$ & $\begin{array}{c}-1.27 e-05 \\
(9.69 e-06)\end{array}$ & $\begin{array}{l}-6.76 \mathrm{e}-06 \\
(5.47 \mathrm{e}-06)\end{array}$ & $\begin{array}{l}-6.57 \mathrm{e}-06 \\
(9.10 \mathrm{e}-06)\end{array}$ & $\begin{array}{l}-5.76 \mathrm{e}-06 \\
(9.86 \mathrm{e}-06)\end{array}$ & $\begin{array}{c}-8.59 e-06 \\
(8.98 e-06)\end{array}$ \\
\hline Literacy & $\begin{array}{l}-0.515 \\
(2.379)\end{array}$ & $\begin{array}{c}4.138 \\
(3.659)\end{array}$ & $\begin{array}{c}-16.20 \\
(11.16)\end{array}$ & $\begin{array}{c}-1.431 \\
(2.000)\end{array}$ & $\begin{array}{l}-3.328 \\
(2.823)\end{array}$ & $\begin{array}{c}3.041 \\
(3.894)\end{array}$ & $\begin{array}{l}-3.408 \\
(3.517)\end{array}$ & $\begin{array}{c}-4.742 \\
(3.248)\end{array}$ & $\begin{array}{l}-5.227 \\
(2.980)\end{array}$ \\
\hline Constant & $\begin{array}{c}303.0 \\
(278.3)\end{array}$ & $\begin{array}{l}-890.5 * \\
(437.5)\end{array}$ & $\begin{array}{l}2,231 * \\
(1,093)\end{array}$ & $\begin{array}{c}437.7 \\
(314.7)\end{array}$ & $\begin{array}{c}594.1 \\
(446.4)\end{array}$ & $\begin{array}{c}78.30 \\
(482.0)\end{array}$ & $\begin{array}{c}252.8 \\
(313.2)\end{array}$ & $\begin{array}{c}527.9 \\
(330.2)\end{array}$ & $\begin{array}{c}334.8 \\
(266.5)\end{array}$ \\
\hline $\begin{array}{l}\text { Observations } \\
\text { R-squared }\end{array}$ & $\begin{array}{c}20 \\
0.379\end{array}$ & $\begin{array}{c}20 \\
0.667\end{array}$ & $\begin{array}{c}20 \\
0.357\end{array}$ & $\begin{array}{c}20 \\
0.759\end{array}$ & $\begin{array}{c}20 \\
0.658\end{array}$ & $\begin{array}{c}20 \\
0.625\end{array}$ & $\begin{array}{c}20 \\
0.262\end{array}$ & $\begin{array}{c}20 \\
0.190\end{array}$ & $\begin{array}{c}20 \\
0.329\end{array}$ \\
\hline
\end{tabular}

Robust standard errors in parentheses

$$
* * * \mathrm{p}<0.01, * * \mathrm{p}<0.05, * \mathrm{p}<0.1
$$




\section{Appendix 1: List of States}

\begin{tabular}{lll}
\hline Bihar & Haryana & Tamil Nadu \\
Chhattisgarh & Jammu and Kashmir & Delhi \\
Maharashtra & Madhya Pradesh & Uttar Pradesh \\
Andhra Pradesh & Karnataka & Orissa \\
Gujarat & Rajasthan & West Bengal \\
Himachal Pradesh & Assam & Punjab \\
Kerala & Jharkhand & \\
\hline
\end{tabular}

\section{Appendix 2: Summary Statistics}

\begin{tabular}{|l|c|c|c|c|c|}
\hline Variables & Observations & Mean & S.D. & Max & Min \\
\hline Informal (Urban & 20 & 745.05 & 83.77 & 853 & 559 \\
+Rural) & 20 & 690.25 & 91.10 & 806 & 441 \\
Informal (Urban) & 20 & 782.1 & 87.70 & 878 & 585 \\
Informal (Rural) & & & & & \\
\hline Corruption (Composite) & 20 & 488.95 & 104.77 & 695 & 240 \\
\hline SDP (2000 - 01) & 20 & 74980.35 & 52296.86 & 210526 & 13262 \\
\hline Literacy & 20 & 66.45 & 10.21 & 90.86 & 47 \\
\hline Population & 20 & 50195.2 & 38004.61 & 166198 & 6078 \\
\hline HDI & 20 & .4086 & .089 & .624 & .308 \\
\hline
\end{tabular}


Appendix 3: First Stage Results

\begin{tabular}{l|c}
\hline & Estimates \\
Population & -.0 .001 \\
Literacy & $(0.001)$ \\
& $-13.60 * * *$ \\
SDP & $(3.65)$ \\
& 0.001 \\
SDP sq & $(0.001)$ \\
& $-2.30 \mathrm{e}-09$ \\
HDI & $(5.53 \mathrm{e}-09)$ \\
& 600.44 \\
Constant & $(419.71)$ \\
& 230.2 \\
& $(183.4)$ \\
\hline Observations & 20 \\
R-squared & 0.678 \\
F test for excluded & 6.95 \\
Instruments & \\
Partial R-sq of excluded & 0.5 \\
Instruments & Standard errors in parentheses \\
\hline \multicolumn{2}{c|}{$* * * 00.01, * *$} \\
\end{tabular}




\section{Appendix 4: State-wise Mandays Lost, Resulting in Work Stoppages Due to Industrial Disputes in India (2000 to 2008)}

\begin{tabular}{|c|c|c|c|c|c|c|c|c|c|}
\hline & & & & & & & & & ('000) \\
\hline States/UTs & 2000 & 2001 & 2002 & 2003 & 2004 & 2005 & 2006 & 2007 & 2008 \\
\hline Andhra Pradesh & 4385 & 1497 & 1718 & 7129 & 957 & 1012 & 2405 & 342 & 637 \\
\hline \multicolumn{10}{|l|}{ Arunachal Pradesh } \\
\hline Assam & 50 & 13 & 20 & 9 & 68 & 112 & 100 & 29 & 288 \\
\hline Bihar & 2078 & 310 & 61 & 60 & 146 & 23 & 124 & 60 & 95 \\
\hline Chhattisgarh & - & & -1 & 13 & 29 & 10 & 27 & 4 & 27 \\
\hline Goa & 59 & 97 & 17 & 2 & - & - & - & - & - \\
\hline Gujarat & 618 & 225 & 102 & 147 & 163 & 187 & 201 & 97 & 43 \\
\hline Haryana & 206 & NA & 571 & 136 & 158 & 494 & 418 & 48 & 5 \\
\hline Himachal Pradesh & 287 & 69 & 20 & 33 & 25 & 23 & 15 & 9 & 11 \\
\hline Jammu \& Kashmir & & & & - & & @ & 9 & @ & - \\
\hline Jharkhand & - & - & - & - & - & - & 56 & -1 & - \\
\hline Karnataka & 504 & 1005 & 322 & 140 & 217 & 458 & 286 & 94 & 213 \\
\hline Kerala & 1498 & 945 & 6961 & 568 & 469 & 3619 & 463 & 227 & 613 \\
\hline Madhya Pradesh & 621 & 172 & 5 & 113 & 55 & 85 & 119 & 12 & 59 \\
\hline Maharashtra & 1755 & 742 & 633 & 547 & 1347 & 1433 & 449 & 1 & 31 \\
\hline Manipur & 8 & 80 & 6 & 10 & 52 & 19 & - & - & - \\
\hline Meghalaya & - & 7 & - & - & -1 & - & - & - & - \\
\hline \multicolumn{10}{|l|}{ Mizoram } \\
\hline \multicolumn{10}{|l|}{ Nagaland } \\
\hline Orissa & 197 & 33 & 5 & 237 & 72 & 122 & 159 & 10 & - \\
\hline Punjab & 151 & 228 & 220 & 314 & 310 & 33 & 110 & 49 & 90 \\
\hline Rajasthan & 741 & 1259 & 1308 & 1308 & 1332 & 1927 & 1335 & 953 & 974 \\
\hline \multicolumn{10}{|l|}{ Sikkim } \\
\hline Tamil Nadu & 2588 & 1842 & 1563 & 939 & 638 & 661 & 720 & 1411 & 806 \\
\hline Tripura & - & 5 & - & - & - & - & - & - & - \\
\hline Uttar Pradesh & 1896 & 367 & 110 & 98 & 185 & 133 & 46 & 42 & 1410 \\
\hline Uttaranchal & & 9 & 10 & 21 & 33 & 39 & 503 & 25 & 12 \\
\hline West Bengal & 10570 & 14847 & 12911 & 18412 & 17565 & 19216 & 12521 & 23738 & 11998 \\
\hline Andaman \& Nicobar Islands & 41 & 2 & 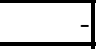 & $\pi$ & - & - & - & - & - \\
\hline Chandigarh & 348 & 9 & 21 & 19 & 12 & 47 & 105 & 6 & - \\
\hline \multicolumn{10}{|l|}{ Dadra \& Nagar Haveli } \\
\hline \multicolumn{10}{|l|}{ Daman \& Diu } \\
\hline Delhi & 160 & 4 & & 2 & 32 & 10 & 154 & 11 & 110 \\
\hline \multicolumn{10}{|l|}{ Lakshadweep } \\
\hline \multicolumn{10}{|l|}{ Pondicherry } \\
\hline India & 28763 & 23767 & 26586 & 30256 & 23866 & 29665 & 20324 & 27167 & 17433 \\
\hline
\end{tabular}

Note : - : Nil.

@ NA : Not Available.

Source: Ministry of Labour and Employment, Govt. of India. 